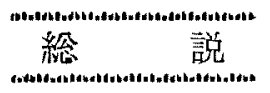

\title{
高分子単結晶の塑性变形機構
}

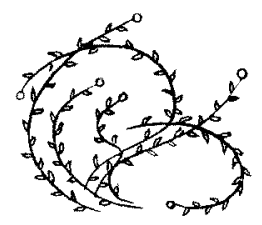

宮坂㤵象

序

論

高分子の塑性変形が重要な問題として注目されるよう になった発端は, 合成瀻維の製造工程中，久くことので きない延伸操作と結びついていることはよく知られた事 実である。し办し，高分子小塑性変形といら染の中で， 結晶の塑性变形が注目されたのは比較的最近のことであ る。これは, 結晶性高分子が非晶と結晶の混在した二相

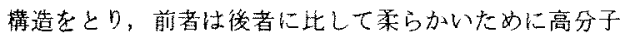
固体の变形は，前者が主体的役割を果すと考元られてい たという事情による。例えばKratky の配向のモデル機 構を考光て屯，そこには結晶の塑性変形を考愿したと思 わ扎るふしは晃当らない。しかし，結晶化速度の大きい 高分子種の未惩伸物(そこではすでに球晶などの存在が 認めら結晶化はある程度進行してしまっている。は数 倍程度の低い延伸率で，充分高度の栈維配向に变化する ことが経駼的に知られてくると, 結晶自身の何らかの变 形を考恿しないと現象の説明が難かしくないてきた。さ らにPEのインフレーンョン膜にみられるように，固体 の塑性変形の難易が，延伸前の試料に扔ける結晶軸の配 向の方向と密接な関俰があることなどの発見は，高分子 固体の塑性変形にお゙いては，非晶よりもむしろ結晶の方 が，重要な役割を果しているのではないかということを 明確に示すものとないた。またさらに，球晶の变形を配 向という視点で捉えたStein, 河合 (弘)ら ら $^{2}$ の一連の研 究の中で、球晶の変形が，単に結晶の回転(配向のた めの)のみでは多くの場合に説明が不可能であり, 結晶 自体の塑性変形の機構の導入の必要性を，末た別の面で 示したものであった。

このようにして㦝在では結晶性高分子固体の大変形は， 結晶の塑性変形と切り離しては考えられないという諗識 は，常識になっている。以下に述べる単結晶の集精物の

\footnotetext{
Mechanisms of Plastic Deformation in Polymer

Single Crystals

KEIZO MIYASAKA

東底工業大学工学部 助教授 (工博)
}

変形はこのような点を背景にして登場したものである。 すなわち，結晶门塑性変形が重要な役割を果すとするな らば，可能な限り単純な系に戻って，そ扎を検討すると いらことが必要であって，この思考方法は 1 つの科学の 定形となっているものである。ここで，触れて执かなけ れでならない点は，綕晶の変形を議論するならば，もっ とも単純な采として、希薄溶液から生成する単結晶者単 独に上り出して謂べるべきであるうといら考えカが当然 の㷌結として生まれるということである。事実この方法 はPEについて木万, Peterlin, Geilら 晶をある種の支持膜上に乗せた状態で，変形を加えると いら方法で具体化さ机て，非常に興昧ある知見を与えた。 ナイロン 6 $\left.{ }^{4}\right) \mathrm{PP}^{5}$ などについてもこの種の研究がなされ ている。ここに報告される主としてわれわれの研究室の 什事は、これらの単結晶集䖽した単結晶の集合体の変 形に関するものである。これは単結晶単体の場合に比較 して，一段と来の複雑さは增寸が，変形時の腵結晶への 力の作用のしかたが，単結晶単体の糃合と比較して本質 的に異なり，一般のバルク陚料の場合とかなり類似的に なるという意味で，バルク試料内に扔ける結晶の変形を 考える場合の，極めて重要な情報を与えるものとみて上 いであろう。

1. 単結晶集積物(マット)の構造的 特徴と与える变形作用

\section{1. a 構造的特徍}

PEの希薄溶液から生成した単結晶を,フィルターで 溶液を濾過させ集積し，さらに溶媒を除いたのちプレス 機で压力をかけると，比較的透明なフィルムが形成され る。これが単結晶マットである。X線回折によって、こ のマットの構造を調べると次のような特致をもつことが bかる。(第1図)

（1）結晶の分子鎖㤝、マットの厚さの方向に平行に配 向するが、 $\mathrm{a}, \mathrm{b}$ 軸はマットの面内でランダムに配向して いる。すなわち結晶軸の配向様式は，マットの厚さ方向 を繊雥軸とする1軸配向である。 
small angle

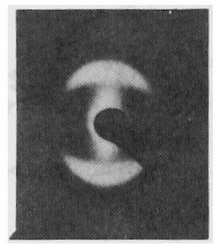

第 1 図 PE 単結晶マットの X 線回折写真 上下方向はマットの厚さの方向でX線は, マット面に平行に入射されている。

（口）結晶の分子鎖を横切る界面は、ほぼマット面に平 行である。これは (イ)の知見と合わせると, 結晶界面と 分子鎖はほぼ垂直であることを意味する。

以上が基本的な特徵であるが, ある程度理想化された ものであり，実際にはかなり広い分布をもっていること が認められる。

1.b マットに与える変形の様式

上記のマットに次の二つの種類の変形作用を加える。

(イ）マット面に平行な伸張昂

(口) 二つのローラー間でのマットの压延 ${ }^{7)}$

このとき（イにについては約 $90^{\circ} \mathrm{C}$ の温度をかける必要が ある。これは, PE の結晶分散温度 $\left(\alpha_{c}\right.$ 分散 $60^{\circ} \mathrm{C} \sim 80^{\circ} \mathrm{C}$ 附近) 以上でないと，伸張による大变形が不可能なため

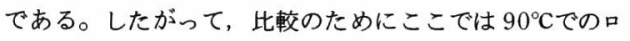
一ル压延の場合のみに注目して行くことにする。(口)につ いて特記すべきことは, 陚料の口ーラー圧延における巨 視的な变形を観察すると，口-ラー間の压縮によって生 じた厚さの减少は，そのまま長さ(口-ラーの周速方向) の增大に変換され, 幅の変化はほぼゼ口になることであ る。したがって, ロール変形の程度は, 試料に生じた伸 びによって表現できる。これをここでは，口ール延伸率 (ג)と呼ぶことにする。

\section{2. 初期変形}

外力の作用によって，マットを構成している結晶は変 形するが，延伸，口ール压延のいずれにおいても，変形 の極限としては, 分子鎖が試料の伸長の方向に完全に配 向して織維構造をとる。このとき, 変形を初期と後期の 二つに分けて考えた方が, 現象の整理に便利である。こ こでいら初期変形とは, 最初から存在している結晶の, 变形として扱うことのできる領域の变形を意味し, 延伸 の場合には, 試料の伸びで $20 \sim 30 \%$ 程度の正, ロール压 延では約 5 倍程度の口ール延伸率の範囲である。

これに対して, 後期変形とは何らかの不連続的な変化 が生じ, 最初から存在している結晶が新たな結晶として
再生してくるような領域に対応する。(緟密にはこの区別 はつけ難いが）もちろんこれが完全に不連続か否かの判 断は, 現在学会でも定説がないが, ここではあくまでも 形式的にこのように分けておくことにする。すなわち, 具体的には, 延伸の場合には, ネッキング变形が後期変 形に対応するものであり，ロール圧延では，巨視的なネ ッキンク現象は起きないが，X線回折などによって不連 続な变化が認められる。

\section{2. a 初期変形の特徴}

初期変形域では, 延伸, 口-ル压延ともに共通に, 次 の上うな結晶軸の配向変化が観察される。(第 2 図参照)

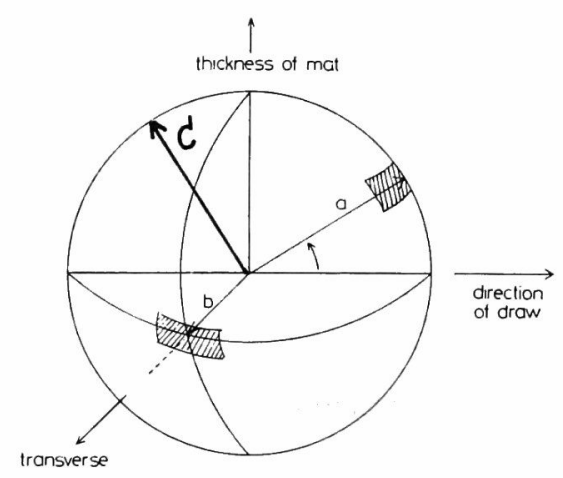

第2 図PE単結晶マットの初期変形にみられる結晶 軸の配向様式

延伸前には $a, b$ 軸は延伸方向と幅 (transrerse）方向で作るマット面内にランダムに分 布している。（イ）延伸の場合にはラメラの界 面はマット面内に平行にとどまるが，（口）口 ール压延の場合には幅方向を軸として回転し

マット面とある角度をもつようになる。

（イ）最初マット面に垂直に配向していた分子鎖軸は, マット面に $40^{\circ} \sim 50^{\circ}$ の範用で傾く。

（口） b 軸はマット面内にはとどまるが, 伸びの方向に 垂直に配向する。

一方, 結晶界面の配向に関しては

（イ）延伸の場合には，界面は常にマット面内に平行で 配向に変化はない。

(ロ) ロール压延では界面はマット面に平行であったも のが，ある程度の角をもって傾いて配向する。

以上の結果, 初期変形では, 結晶内で $(100)$ 面に沿 っての滑りを, 内容とする分子鎖の tiltを起しているこ とが結論される。すなわち, 結晶界面は最初分子鎖と垂 直であったものが, 初期変形では数十度傾いてくる。し かもその傾き方は，ちょうど b 軸のまわりに，分子鎖軸 が回転するような方法で起ることを意味する。(陆) 


\section{2.b 初期变形の籹構}

\section{(1) b 軸の配向}

さきに述べたように，最初マット面内でランダムに即 向していた $\mathrm{b}$ 軸（その状態では $\mathrm{a}$ 軸も同じ)は，変形の 初期ではマット面内には残るが，伸張と垂直の方向に配 向する。口ール圷延の場合には，初期変形は延伸率 5 程 度に及ぶが，このb軸の配向はもっと小さい延伸率の上 ころで起きていることが確認される。ここでなぜこの ようなb軸の配向が起るがを、木方らの単結晶単体の变 形と対比して考察してみよう。木万らによれば, 単結晶 の変形挙動は, 伸張力向と結晶朝の向きとの関倸に依存 する。したがって, 単結晶単体と, マットにおいて同一 の変形挙動が起きるものとすれ拈，彼らによって分類さ れた幾種類かの变形が同時に起きることが期待される。 しかし，実際は上記のように、、ットの場合には，初期 変形によって生ずる結晶軸の配向変化はほぼ単一であり, 最初の結晶の方位とは，ほとんど完全に無関倸に，一定 に揃ってしまう。これは，戦一結晶で筧察される变形と， その集合体におけ石そ玌とは，著しく異ることを端的に 示すものであり，これは序論において述べたバク試料 との对伈考考える昜合に，もっとも単純な系として，集 積マットが考えられねばならないということと対応して いる。

一見, この上らに，支持膜上に置かれた単結晶単体の 変形と, マットのそれとは似ても似つかないほど異った 様相を呈するが, 前者で見出されている变形の機構を導 入することが，後者のそれを考えるときに，役立つこと むすくなくない。

ここで，伸張の方向に対して，1）a 軸が平行，W b 軸 が平行の二つの場合のみについて，単結晶単体とマット における変化を比較してみる。

第1表はこの二つの場合についての变化を示したもので あるすままず、軸の方向ての伸張では，単結晶では $\{110\}$ twin が起って，a軸は最初の方向から数十度分子鎖軸 のまわりに回転するのに対して（第3図参照)マット ではこのような回転は起らずそのままb軸のまわりの回 転（tilt）を起すのみである。したがって両者の間に，何 らの相関を見出すことはできない。これは，単結晶は支 持膜上におかれ，支持膜の伸張により間接的に力が結晶 の下側の界面に沿ってのみ作用しているという事情が, 大きな原因であると考えられる。マットの場合には，単 結晶か゚集樍して一つの固体を形成しているために，構成 する単結晶は，一般の固体と同梾にポアソン力を含んだ

(泩)ロール王延の㛫合には，上記のように界面の回転む起きるが，

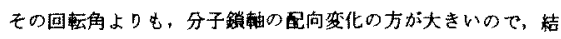
晶内で分子の tilt が起きていることがかかる。

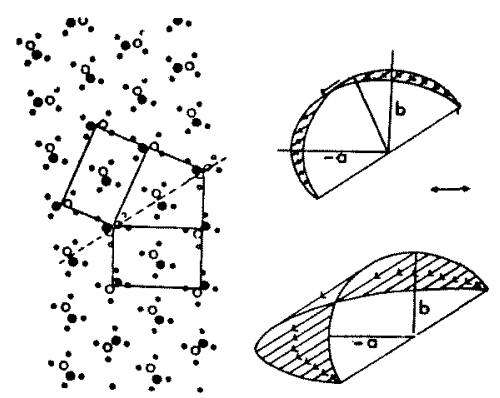

第3图 单結晶のa軸の力向への伸張によって生ず る $\{110\}$ twin. $^{\text {s) }}$ 両矢印は伸張の力向

第 1 表 単結晶单体とマ\%トの初期 変形における变形举動の比較

\begin{tabular}{|c|c|c|}
\hline & 事結昆 ${ }^{8}$ & $\nabla \%$ \\
\hline 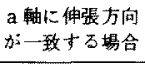 & $\{110\}$ twin & b軸のまわりでの分子銷のtilt \\
\hline $\begin{array}{l}\mathrm{b} \text { 蟄に伸張方向 } \\
\text { 加一致す西場合 }\end{array}$ & 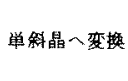 & 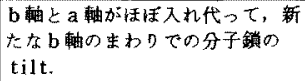 \\
\hline
\end{tabular}

むのとなり，比較的均一なずり応力が発生して扔り、こ れが分子の tilt を容易にしている。この(100) 面に沿 っての滑りは，他の变形に比しもっとも低いェネルギー で起ることはよく知られた事実である。

次にb軸方向の伸張についてみると、これも表た両者 屿著しく異なる変形举動を示している。しかし，単結晶 単体でみら扎る変形の機楧を用いると、マットでみられ るb軸が，伸張方向からマットの面内で，90回転する という結果がうまく説明できる。すなわち，木机によれ ば，b軸にほぼ平行な方向への伸張では，単結晶は第 4 1 図のような単斜晶への相変化を示す。さらに、第 4.2 図に引用されたようにb軸と伸張方向とのなす角が，第 4.1 図よりももう寸こし大きい場合にも，同様な相変化 が起るが样式は第 4.1 図上異っている。(木方らの命名 によれば，第 4.1 网はタイプ1，第 4.2 図はタイプ $3 の$ 引張り様式である。）マット内でb軸が伸張の方向と一 致する配位をとる結晶がある場合に，むし，(010)滑り が (100)と同程度の容易さで起るならば, そのまま(010) 滑りをともなう tilt が発生することが,これまでの結果 から予測されるが，(010)滑りは（100)に比して起きに くい。したがのて，括そらく単結晶单体の場合のように， 第 4 図に類似の相変化が起ると思われる。一方ここのよ うにして生ずる単斜晶は，著しく不安定である（熱的に も応力的にも)ために，再びもとの斜方晶に戻万うとす 


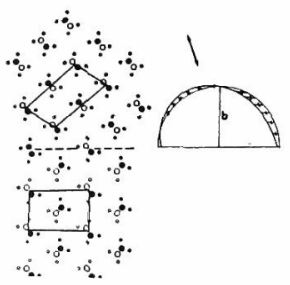

I

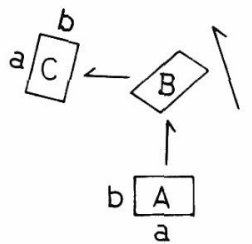

3

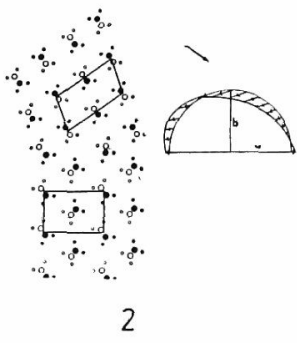

第 4 図 PE 単結晶の伸張 によって起る単斜晶への 転移 $(1,2)$ と二つの転移 の結合 (3)

3 では, Aが B (単斜晶) へ1の過程で相転移し 次いでBは 2 の逆の過程 でC (斜方晶)に戻る。 この結果, 変形後, 結晶 軸( a, b) はほぼ $90^{\circ}$ 回転 する。これは結晶内にお ける変化なので, 結晶全 体としての回転とは無関 係である。

る。

このとき，第 4.1 図の過程をそのまま逆に戻れば, 軸 の配向変化は全く起らないが，第 4.2 図の型の逆の变換 をたどるとすれば， b 軸と a 軸はほぼ完全に入れ代った 状態で，斜方晶への逆変換が起る筈である。（第 4.3 図 参照)このような機構が，実際に起っているという実験 的な証明は得られないが，ここで注意しておきたい点は， マットの変形でみられる特徵的な $\mathrm{b}$ 軸の配向変化の挙動 は，決して結晶全体としての回転によるものではなく， 相変化や twin など結晶内での変化が, 段階的に起った 結果として生ずることは間違いのない事夷と認めてよい であろう。なお，さらに，ここでの延伸，ロール车延い ずれの場合にも，伸びの方に垂直な面内での試料の変 形は，極めて異方性が高く，幅の方向はほとんど収縮し ないという事実は変形に際して，幅の方向に沿って，実 際に潜在的にかなりの伸張力が加えられていることを意 味するものであり，結果的には完全な 1 軸伸張変形では なくなって，一定幅 1 軸伸張の様式になっていることも 留意しておくべきことであろう。

（口）分子鎖の tilt.

初期変形における第二の特徵は，b 軸のまわりの回転， すなわち(100) 滑りを伴う分子の tilt である。(第 5 図 参照) この tilt は転位によって生ずるものと考えられる
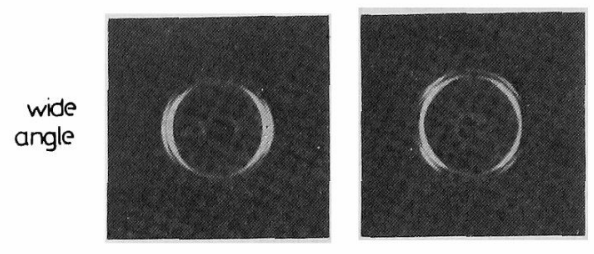

small
angle
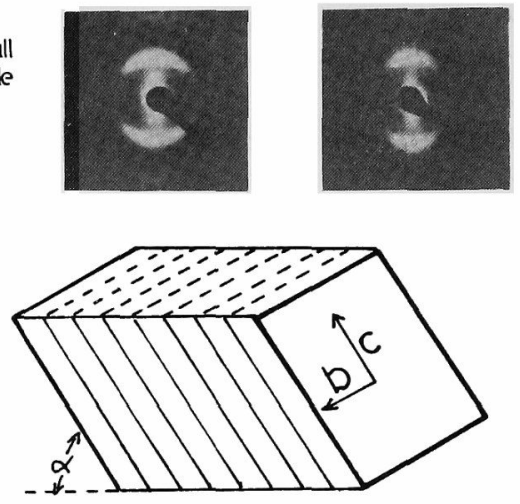

第 5 図 (100) 滑りを伴う結晶内分子の tilt. 上のX線写真右側は単結晶マットの延伸でネ ッキングを生ずる寸前（約 $20 \%$ 伸張）のもの ( 入射 X線は延伸方向に垂直でマット面に平 行 ) で，分子の tilt が下の図のような様式で 起っていることを示す。下の図の太線の面は (100)面に対応して, b, c はそれぞれ b 軸と 分子鎖軸の方向を示す。ロール圧延の場合に もこの様式の tilt が起る。左側のX線写真は 変形前のもの。

が，(h00)面内でのらせん転位が優勢であり，刃状転位 の可能性は極めて小さいと考元てよいであろう9. 10)

(100)面の滑りは, らせん転位によって容易に起るであ ろうが, ここでいう tilt とは結晶内の全ての単位格子に ついてもれなく, この種の滑りが起った状態を意味する ので問題は複雑である。すなわち，この種の転位が結晶 の一つの場所で, 滑りを形成したのち次々と伝ぱするか, 上記の転位源が均一に存在して, 次々に転位が形成され るか二通りの可能性が考えられるが，そのいずれも，実 祭的ではなく不可能に近いであろう。考えられることは, 均一な転位の発生によるのではなく, 結晶はらせん転位 によってある程度のブロックを形成して滑り，同時に界 面についての要請から回転を起すが，变形の進行ととも に，そのブロックの中で転位が形成されブロックが細分 化され，それが污る程度進行したとき，結晶は新たに再 編成されるのではないかと推定される。この再編成とい う言葉は, 自己修復性とも言い代えうるものであって, 
第2 表 線状ポりエチレン単結晶マット の初期变形前後の長周期 0 比較 ${ }^{6}$

\begin{tabular}{|c|c|c|}
\hline 試 料 & \multicolumn{2}{|c|}{ 辰周期 $\AA$} \\
\hline (結晶化温度) ${ }^{\circ} \mathrm{C}$ & 㱠形前 & 姿形啳 \\
\hline $90^{\circ}(\mathrm{a})$ (垱) & 141 & $135(100)$ \\
\hline $85^{\circ}$ (a) & 134 & $125(92)$ \\
\hline $70^{\circ}(a)$ & 116 & $111(82)$ \\
\hline $60^{\circ}(\mathrm{b})$ & 107 & $105(76)$ \\
\hline
\end{tabular}

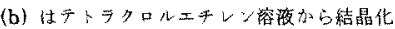

ある意味では高分子特有の性質とみてもよいで古ろう。 この意味をもっと具体的に理解するために，策2表が用 意さ机ている。この表は延伸の際の初期変形での結晶の 厚さの変化を示したものであり，試料は結晶化条件を変 えた四種が用いられている。約 $20 \%$ の伸張によって結晶 の厚さ(小角線長周期をその亦厚さと㧍き代えても，

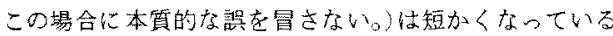
ことがわかる。変形前に界面に垂直に立っていた分子鎖 は，20\%延伸徯約 $45^{\circ}$ 傾いている。したがって，結晶を 貫く分子鎖の银さが一定に保た㧈るものとすれば，最初 の厚さに $\sin 45^{\circ}=1 / \sqrt{2}$ 倍した值が，变形得の厚さにな る筈である。このようにして子測される值がカッコ内に

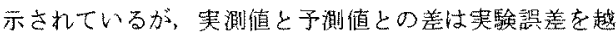
えている。この事事は，結晶は恋形の過程で結晶鎖を長 くするような別の変化を起していることを示す生のであ り，このようなこと䘮ここで自己修復性と呼ぶのである。 これは，上で述べたような機楧で転位によるブロックを 単㕸とする滑りが，次第に進行するにつれて，結晶が不 安定化し，これを補うために事実上の摩化を起している と解积すべきであり，高分子結晶の変形が，単に最初与 えられた結晶の転位による変形のみを生ずるのではなく， 付加的に別の現象（広義の熱処理）む伴っていることを 端的に示すものと理解できる。上記の tilt の問題に戾れ ば，各単位格子毎の均一な tilt むまたこの上うな付加的 な現象との協同の結果，はじめて達成されるものと考兊 ねばならないであろう。

さらに tiltに関して注目して扔くへきことは，初期変 形での tilt の進行は大体 $40^{\circ} \sim 50^{\circ}$ の範用(結晶界面と分 子鎖軸とのな角が)でとどまりこの值へは非常に早く 到達し，以後飽和することである。そ扎以上のtiltの進 行は，後期変形における不連続的な变化を伴わねばなら ない。

分子結晶内での tilt と直接関倸はないが，ここで触れ て扰ぐきこととして，口ール正延の場合には結晶界面 の回転が起ることである。最初マット面内に平行であっ た界面が第 6 图に模式的に示されるように、マット面か

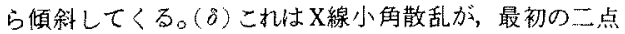

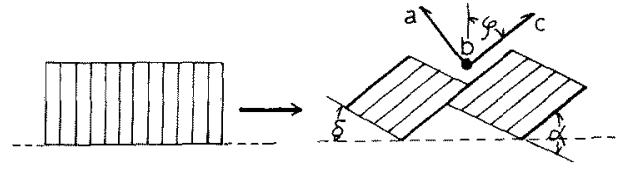

第 6 图口-ル压延における初期変形の模式図 知印は口ール王延の方向，点線はマット面 （紙面に垂直）を表わす。 左側は王歹前の状態を指寸が，分子鎖（c軸） が紙面上で上下の方向をとるだけで、、bはマ ット面内にランダムに配向している。 右の図では結晶の紐分化, tiltと同時に結晶 軸の配向が起る。b軸社縒面に垂值である。 延伸の場合には上の図で $\delta=0$ となる。

像から四点像に变化してくることから㷌結さ扎る。(小 角散乱でこのような像を生ずることは、ットの厚さの 万向に皘み重なった単結晶（細分化された）加，すくな くとも数コが同時に一体となって可転していることを意 味する。分子鎖軸の回転が，この結晶の回転にのみよる ものであ机代，両者の回転角は一致するが，実際には前 者が後者を大きく上回り，上記の tiltが䚻結されるので ある。(第6四のれが $90^{\circ}$ り小さくなる)結晶のこのよ うな回転には，結晶のプロ，ク化が必然的に要求される が，口一ル压延に挍ける底力成分の多様性が，この細分 化と回転に有效に作用しているものと考えられる。

\section{（六）变化の均一性}

こ机まで述べてきた単結晶マットの初期変形に含まれ 素過程は，ある程度単純化され理想化されたものであ る。実祭にはこの法則から外机るものもある。とくに， 口-ラ一正延の場合にその不均一性は著しい。例宎ば， ローラ一压延では，(010)滑りを伴う分子のtiltが(100) と全く同じ様式で一部起っているし，単斜晶への变換が 除重後もある程度安定に残っている。

\section{3. 後期 变 形}

最初から存在卞る結晶の峃純子塑性变形としては，捉 えられない領域老意味するが，この恋形の結果，分子鎖 は伸張の方向に恬とんど完全に配向する。上でも述べた ように，変形初期に扔いても，必ずしも単綪な塑性変形 のみではないが，この領域ではをれが著しくなる。この 変形後期では，延伸と口ール压延ではかなり異った様相 を是するので別々に扱うことにする。しかしいずれの場 合にもこの領域に㧍ける変化は，分子鎖の配向に関する 限りは，初期变形の单なる進行に過ぎないことは，最初 に指摘して弶く必要があるう。

(1) 延伸の場合 
この場合の特徵は，蹞著なホッキンダであり，ネック 部分での延伸率が数十倍に達し，分子が完全にとさほぐ さ扎た (unfolding)"上したときに期待さ㧈る延伸率に かなり近い㥀をとることである。司

4 種の結晶化条件の異なる単結晶より作成したマ, ト の，伸張前の長周期(結晶の厚さに近いとみてよい)と 延伸率が第3表に示されている。この表の最徯の列には

第 3 表 線状ポリエチレン単結晶マットの長周 期と延伸率（ネック部分での延伸率）

\begin{tabular}{|c|c|c|c|}
\hline 試 科 & 变形前の展周期 $A$ & 超伸率 & $L / L$ (牛) \\
\hline 結晶化鼬度 9 & & & \\
\hline $90(a)$ & 141 & $35 \pm 3$ & 31.7 \\
\hline $85(a)$ & 134 & $30 \pm 3$ & 30.1 \\
\hline $70(a)$ & 116 & $23 \pm 2$ & 26.7 \\
\hline $60(\mathrm{~b})$ & 107 & $20 \pm 2$ & 23.9 \\
\hline
\end{tabular}

長周期 $L$ 索(110)に沿っての隣接分子間距醀 $l$ で割的た 健が示されている。もし，仮りに(110)に沿って分子が 折りたたまれているとして，その方でunfoldingが起 るとすれ忧，この䛧は延伸率を与えることになる。両者 の梿が comparableであることは示唆的である。もちる ん，このような unfolding 加実際上起きているか不かを 証明する何物もないのでこれ以上の議論は難しいが，延 伸率についてのみ注目すれば， unfoldingによるとして むあまり大きなむじゅんは無いと言うことは可能であ らら。また延伸物の物性も，unfoldingした鎖がかなり 多くの tie chain むった状悲で再結晶化したと考える う理解されやすい。

\section{(口) ロールE延の場合}

第7図は口一儿延伸率入に対して门)結晶分子鎖の配

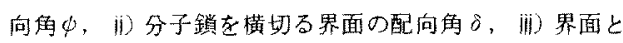
分子鎳のなす角（tilt角）ぬををれぞれプロットしたもの である。各々の定義は第6図に示さ机ている。申の变化 からみるとス=7 以上では分子鎖はほとんどロール延伸 の方向に配向していることがわかる。この分子鎖の $90^{\circ}$ の回転は a) 結晶の回転とb)結晶内での分子鎖の回転， 換言才好诂，結晶内 tilt の二つの効果の結合によって生 じたものである。

前者山界面の配向角 8 で表現されるものである。これ らのパィーター $\alpha_{1}, 8$ はいず扎も $\lambda=5 \sim 7 の$ 範团で 不連綂的に变化している。こ机がロ一ル正延に括ける後 期变形に対応する。この図から明らかにされることは， 第 1 に $\lambda=5 \sim 7$ の範用での $\delta の$ 变化が著しいことであ

(性)一般にヘヘクの延伸で，数十等の延伸率を得ることは可能 であるか，その場合以はネック部分ての延伸等は小さく、高い 延伸率洁，ネックを调ぎてかららの廷伸に角うとこるが多い。

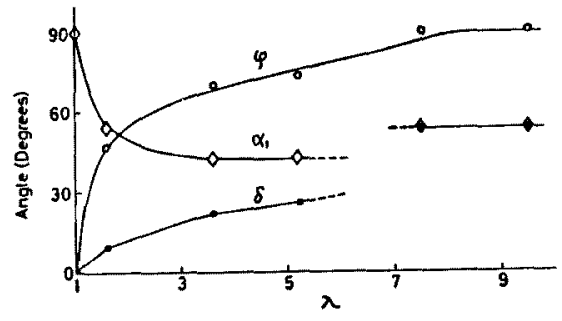

第 7 図 単結晶マットの $90^{\circ} \mathrm{C} に$ 招けるロール生延に よ。て生ずる分子鎖の配问角 $\phi$, tilt 角 $\alpha$,

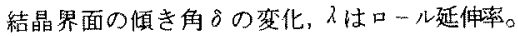
$\lambda=5 \sim 7 の$ 籍㽢での急激な構造変化が, この 場合の後期変形に対庞子る。

常温の口ール正延では，この変化は $\lambda$ の大き

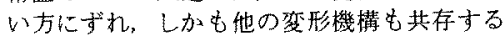
よらになる。

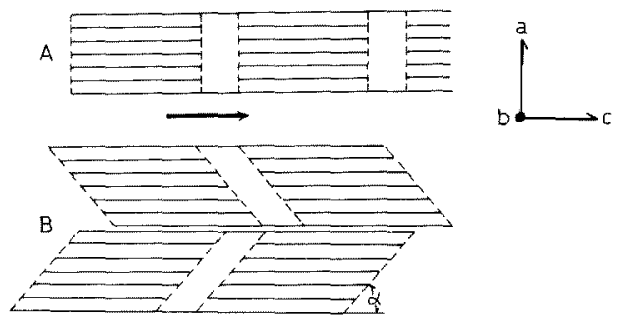

第 8 図 後期变形によって生ずる構造

A. 延伸の場合 B. 口一几压延の場合 矢印は伸びの方向袁わすが，最初のマット 面はこの知印を含さ紙面に垂直な面である。 $\mathrm{A}, \mathrm{B}$ い゙れの場合にも右側に示された結晶軸 の毁向様式をとる。

り，これは後期变形の主体的な機構が，結晶の回転であ ることを示崚するものと考充られる。第2 和第 1 の結果 とも関連するが，入の比較的狭い範囲で急激にこの变化 が起ることで，延伸率の点からみて unfolding の機構は 全く考えられないことである。このような推諭を前提と したときに，ロール正延に站ける後期变形の機檴は次の 節に示されるような姿をとるであるうとわれわれは考え ている。

上で述べたように後期変形では，界面の配向角 $\delta$ は急 激に変化し結晶の回転が顕著に起ることがわかるが，同 時に初期変形域で進行してきた結晶内での分子のtilt 逆にすこし回復する。これは, 初期変形の項で触れた結 晶のもつ自己修復性がここでも発現されているとみる心゙ きである。後期変形によって生じた構造の模式を第 8 图 に香す。 


\section{4. 融解・再結晶を伴わない後期変形機構}

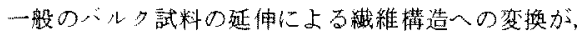
既存の結晶の䖪解と再結晶化によるとする考え方は， Peterlin ${ }^{11}$ が延伸前のX線小角散乱の長周期が，延伸後 に延伸の条件に上って決まる一定檤に落方つくという， 実糇事実にもとづいて導いた極めて納得されやすい考え

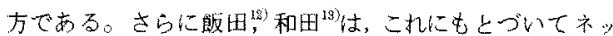
夕部分に抬ける相平衡想定し，定式化し一応夷駰事事 がらまく整理されること京している。

ところで，融解を考えるとさに morphologyの立場て

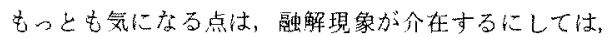
その前娞の関保があまりに㐬すぎることである。

(第6図と第8図のB老比較) 具体的に孙ば，上の

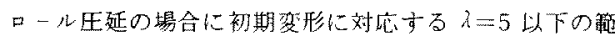
围では明らかに既存の結晶住融解せずに变形を行なって いる。また $\lambda=7$ 以上の範围での tilt 角は， $\lambda=5$ 以下 のそれと非常に近い值をとっている。これは，既存の結 晶が塑性変形に上り初期変形索完成したのち，融解・再 結晶化し新しい搆造が発現したとみることに抵抗を与え る。この婸合を含奴, Peterlinの結果を融解・再結晶 の機構を導入することなく説明づけることは容易である。 変形の過程での非晶を基集とした，結晶の自由エホ几 ギー $\Delta f_{c}$ は次式で与えられる。

$$
\Delta f_{c}=\Delta f_{c}^{\prime \prime}-\triangle f_{S}-\triangle f_{D}-\triangle f_{e}
$$

ここで $\triangle f_{c}^{6}$ は理想結果， $\Delta f_{S}$ は界面， $\triangle f_{D}$ は知部 分， $\triangle f_{f}$ は弾性歪エネルギーにそれぞれ対応する。 $\Delta f_{S}$ ， $\triangle f_{D}, \triangle f_{e}$ はいずれもも正， $\Delta f_{c}^{n}$ は变形中の非晶のエネ儿 ギー状態によって增加するが， $\triangle f_{c}$ は減少しているとみ て上い。販田，和由らの考え方は $\Delta f_{c}=0$ を融解策件と してこ机平衡論的に扱らものである。さて， $\triangle f_{c}$ がゼ ロになる以前に結晶は何らの変化も起さないと考劣る理 由はない。ここで，次のよく知られた费験事军を思い出 してみよう。小角X線長周期を温度を変化して測定する と, PEやPOMのような分子間力の比較的弱い高分子 種では，融点から数十度下の温度の笧囲では長周期は温 度の関数上して可道的に变化する。 には増大し降温時に法減少し，この温度箸柬を越えた低 温では熱膨張に上る砤小な变化を示すのみで，ほぼ一定 值にとどまる。この結果の解䣋としては、結晶の等さか 充分高温では温度で一義的に定まる平衡論的な性質索も っていると考えることがもっとま自然である。充分高温 というのは，融点に近いといら意陎である。さて，式(1) の $\triangle f_{c}$ は变形中に低下しているので，当然その触点は低 下吋る。この融点の低下はを机に代ずいする結晶の厚さ が，可进的に变り得る温度域も当然低下させる。低
下した温度域にもし変形下の結晶の招かれている缊度 (真の延伸温度) が，入ることができ扎ば，てれに対応 して結罩の暨さは增大寸るか减少することが期待される。 もし既在の結晶の厚さがいま与スられた状態に括ける厚 さよりも厚け扎ば薄くなるし，逆の場合には厚くなる。 この上うな厚さの变化が起ること注，同時に tilt角の変 化などを含む結晶の安定化の作業が起をることを意味す 古。

3の(口)でみたロール区延の後期変形や一段のバルク 試料のネッキング延伸では，このような機满にもとづく ものが多く，この機構と結晶の回転とが，同時的に主体 的役割を果しているものとわ机わ执考元ている。

な㧍，飯田・和田らの融解の取り扱いが比較的きれい な結果を与えている理由は，上钎の上らに結晶の厚さや tilt の変化が，自由に行なえる温度域が，融点に近い比 較的狭い温度域であるために，骶点孛指摽にすることて も大きな䛊りを冒さないことによると考光られる。

\section{5. をとめ}

以上PEの単結晶マットの变形についてわれわれの行 なってきた実験を主体にして解説を加えてきたが，最徭 にこ机らについてのまとわとして，一，二の重要と思わ 扎る問題について述べることにする。

初期变形では延伸，ロ一ル王延ともに分子鎖に直交す る結晶軸，才な⿰力口, $\mathrm{a}, \mathrm{b}$ 軸の配向の变化は，著しく特 致的で結鼠自体の回転によるもので忙な，結晶内での 単斜晶への変換や，twin といら素過程を介しての軸変 換によるものであることを示した。これはPEの場合に 限らず，抢そらく他の高分子種の場合にも其通性をむつ ことが予想さ机る。異なる結晶形をもらうるものは， ， イロン6，PPなど多く知られて㧍り，twinもまた同様 である。したがってこのような場合には，延伸の過程 で分子鎖と直交寸る結晶軸恃，不連続的に軸の配向を变 えうる可能性をもっている。

この変化と亚び初期変形で重要なものは結晶内の分子 のtiltであり，こ机恃事情の許す限りは，結晶のもっと も滑り易い面に沿っての滑りを伴う分子のtiltであり, 水来結合を有するものでは，水素結合面がこれに当るこ とが容易に推定される。

後期変形に括いては，unfolding と考えてもよい場合 もあるが，(丹）結晶の回転と(口)变形下での融点降下に 伴って低下する結晶内分子鎖の運動の自由度が，平衡論 的に保証される温度域を释過することによる結晶の厚さ の調整などを主体とする変化の二つが，同時的に主体的 な役割を果す場合が，一般的であると考えられる。その 踏，既存の結晶の融解・再結晶化索考えてもよいが， 
morphologyの立朢では，無理な点が多いように思われ る。

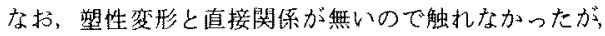
変形中の結晶の細分化は, 以後の回転などに不可欠の要 素となっているという意味で，重要な素過程とみられる。

最後に最近Ohde $ら^{\text {in }}$ の年結晶マットの王縮変形につ いて触扎て扝くことにする。単結晶マ...を二つの面で 王縮すると最終的に変形の力向に分子鎖軸は配向する。 これは，まず第 1 段階として，ラメラ間の滑りが起り， 同時にラメラ内で分子鑽軸に沿ってのく001>滑りまた は分子の tilt の両方または一方が起る。次の段階は不均 一な局所的な滑りが起り細分化されたラメラの破片の回 転が生ずる。さらに，分子鎖軸に沿っての滑りについて 詳細な議論を行なっている。基本的には，上で述べた単 結晶の延伸や，ロール王延の場合と非常に類似している。 な㧍、いったんマットに低延伸を加え配向をもたせたも のについての王縮変形についての研究も" ${ }^{\mathrm{IB}}$ 同じような結 果を与交ている。

[付記] 単結晶マ...トの延伸上,バルク陚料の口ル止延についてはそれぞれ文献 18，19，20を参照された い。また、くルク陚料を用いたPEの結晶の变形につい ては瀬䎡の文献 21 を参照さ扎たい。

\section{文献}

1) K. Kobayashi, Polymer Sengle Crysrals (P. H.Geil著) Wiley, New York, 1963, p. 473 に引用

2）この方面の研究ですっとも新しい報告として次のものを学将て おく。劷しくはこの文献の束尾の引用文献を佥照されたい。 日比貞能, 前田松夫, 小田隆。山田和夫, 野村春治, 河合弘迪, 﨎䑾学誌，28，204 (1972)

3) H.Kiho, A.Peterlin, P.H.Geil, J. Appl. Phys. 35, 1599 (1964), J.Polymer Sci, B 3, 157, 257, 263 (1965). A.Peterlin, P.Ingram, H.Kiho, Makromol. Chem., 86, 294 (1965)

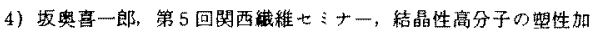

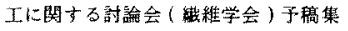

5) P. Cerra, D.R.Morrow, J.A. Sauer, J. Macromol. Sci, (Phys). B. 3, 33 (1969)

6) K. Ishikawa, K.Miyasaka, M.Maeda, J. Polymer Sci, $A-2,7,2029$ (1969)

、ッ卜延伸物心措造物性関係では，M.Maeda，K.Miyasaka， K.Ishikawa, J. Polymer Sci, A-2, 8, 355 (1970), 8, 1865 (1970)

7) 山田三男, 宮坂啓象, 石川欣造, 第 20 回高分子討諭会子稿望 第 冊. p.835 (1971)

8) 単結晶については文献 3 の第1. 番目の文嗝

9) H.D.Keith, E.Passaglia, J.Res. NBS 68A, 513 (1964)

10) 标样，文献 4

11) R.Corneliussen, A.Peterlin, Makromol, Chem, 105 , 193 (1967)

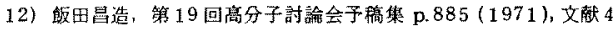

13）中山胃，和白八三久，第 19 回雇分子年次大会 $(1970)$

14) K.O'deary, P. H.Geil, J. Macromol. Sci. (Phys) B 1, 147 (1967)

15) Y.Aoki, A.Nobuta, A.Chiba, M.Kaneko, Polymer Journol, 2. 502 (1971)

16）前田，宮顷，石川，高分子化学，26，241（1969）

17) Y.Ohde, H.Miyaji, K.Asai, J.J.Appll. Phys., 10, $171(1971)$

18）山田三男，宮纳砶象，石川欣造，第19 回高分子討論会 (1970)

19) (单結晶), W.O. Staffon, J. A Appl. Phys., 38, 4149 (1967), P. J.Holdswovth and A.Keller J. Polymer Sci., A-2, 6, $702(1968)$

20) (口ール梴), F.C.Frank, A.Kreller, A.O'connor, Phil, Mag. 3, 64 (1958), B.Maxwell, P.H. Rothshild, J. Appl. Solymer Sci, 16, 811 (1961)., I.L.Hay, A.Keller, J.Mat.Sci., 1, 41 (1966), I. L. Hay, A.Keller, J.Mat. Sci, 2, 538 (1967), J.J. Foint, G.A.Homes, D.Gezovich, A.Keller, Kolloid-Z. und Z. Polymere, 242, 1151 (1970), D.M.Gezovich, P.H.Geil, J.Mat, Sci., 6, 509 (1971), ibid, 6, 531 (1971)

21) T. Seto et al, J.J. Appl. Phys., 7, 31(1968), 8, $166(1969)$, 田島, J.J. Appl. Phys ., 1973 年 1 月号予定

(眧和 47 年 8 月 29 日受理) 